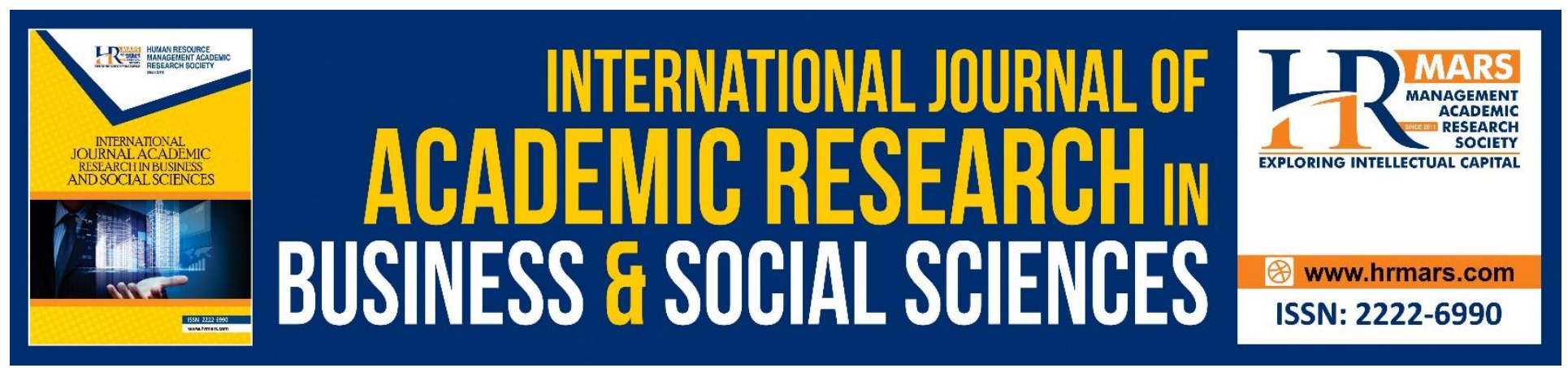

\title{
Audit Committee and Internal Audit Function towards the Quality of Zakat Distribution Performance in Malaysia: A Propose of Study
}

Norlizawati Abd Rahman, Mohd Abdullah Jusoh

To Link this Article: http://dx.doi.org/10.6007/IJARBSS/v8-i12/5430

DOI: $10.6007 /$ IJARBSS/v8-i12/5430

Received: 17 Nov 2018, Revised: 22 Dec 2018, Accepted: 30 Dec 2018

Published Online: 09 Jan 2019

In-Text Citation: (Rahman \& Jusoh, 2018)

To Cite this Article: Rahman, N. A., \& Jusoh, M. A. (2018). Audit Committee and Internal Audit Function towards the Quality of Zakat Distribution Performance in Malaysia: A Propose of Study. International Journal of Academic Research in Business and Social Sciences, 8(12), 2183-2194.

Copyright: (C) 2018 The Author(s)

Published by Human Resource Management Academic Research Society (www.hrmars.com)

This article is published under the Creative Commons Attribution (CC BY 4.0) license. Anyone may reproduce, distribute, translate and create derivative works of this article (for both commercial and non-commercial purposes), subject to full attribution to the original publication and authors. The full terms of this license may be seen at: $\underline{\text { http://creativecommons.org/licences/by/4.0/legalcode }}$

Vol. 8, No. 12, 2018, Pg. $2183-2194$

http://hrmars.com/index.php/pages/detail/IJARBSS

JOURNAL HOMEPAGE

Full Terms \& Conditions of access and use can be found at http://hrmars.com/index.php/pages/detail/publication-ethics 


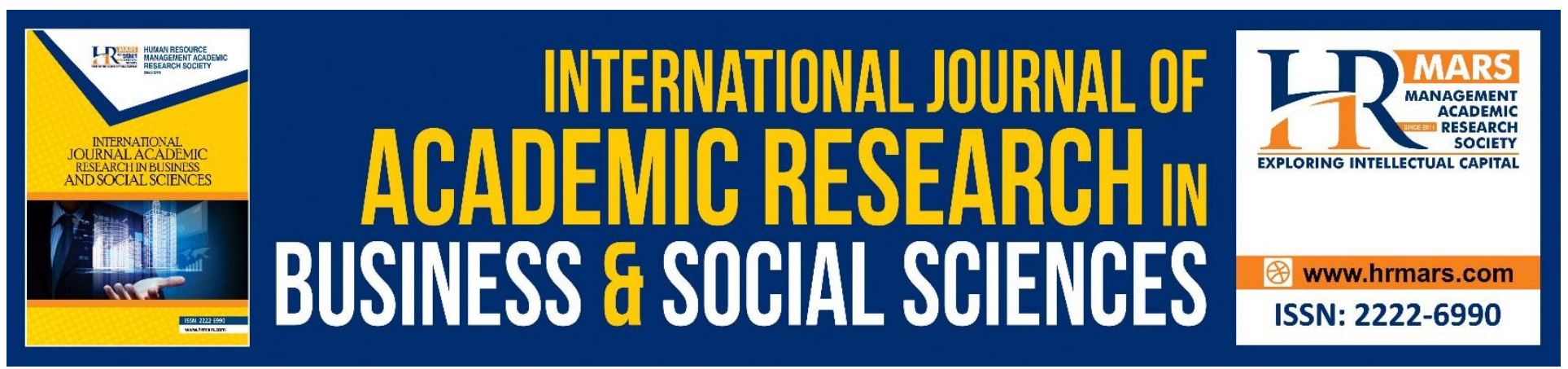

\title{
Audit Committee and Internal Audit Function towards the Quality of Zakat Distribution Performance in Malaysia: A Propose of Study
}

\author{
Norlizawati Abd Rahman ${ }^{1}$ \\ Mohd Abdullah Jusoh² \\ Commerce Department, Politeknik Sultan Azlan Shah, 35950 Behrang, Perak, Malaysia ${ }^{1}$ \\ Faculty of Management and Economics, Universiti Pendidikan Sultan Idris, \\ 35900 Tanjung Malim, Perak, Malaysia²
}

\begin{abstract}
Recently, quality audit committee and effectiveness internal audit function is needed by organization in order to ensure its function meets the best performance. Both of the unit is complement each other in setting the focus to meet the aims as notable trusted body for the collection and distribution of zakat funds. This study will focus on the quality of zakat distribution performance. Besides, identify the relationship between quality audit committee and effectiveness internal audit function on the quality of distribution performance of zakat institution. Next, research hypotheses are being developed based on the previous study been reviewed and the conceptual model will be proposed. Finally, conclude with the suggestion for interest future research.
\end{abstract}

Keywords: Audit Committee, Internal Audit Function, Performance, Zakat Distribution

\section{Introduction}

Malaysian zakat institution has been established to implement all matters related on collecting and distributing zakat to the qualified recipients (Eza Ellany, Mohd Rizal, \& Mohamat Sabri, 2014). The institution exercises the power and authority over an organization on behalf of the community it serves. In order to become the survivor of the Islamic service provider to community, the institutions have to improve zakat collection and effectively distribute the funds to recipients (Sani Adamu \& Ram Al Jaffri, 2016). For this reason, the quality of top management practices is significantly important in order to ensure its sustainability in long-run (Zaemah \& Norhafiza, 2016) especially in zakat institutions. Prior study by Hafizah, Azizi, and Ram Al Jaffri (2016) in discussion about managing zakat funds, find that the equitable distribution of zakat income in society could be achieved through the effectiveness of zakat management. 
Currently, zakat distribution pattern of each institution is different among several states and showed the different level of efficiency on distribution performance (Hairunnizam, Sanep, Mohd Ali, \& Maryam, 2016). Nevertheless, at present, there is still no standardization in the management funds among zakat institutions in Malaysia. Although the administrative structure of zakat management varies by each state, but the efficiency of the distribution have to be assessed in the aggregate not specific to each country. Among the researcher, they believe that the effectiveness of zakat is depends on the method of distribution and also the purpose of it (Fuadah, Ahmad Fahme, \& Muhammad Ridhwan, 2015). The problem here is whether the ultimate purpose of zakat to help the Muslim community in Malaysia could be achieved through the divergent pattern of distribution among zakat institutions. Therefore, the difference in zakat distribution performance have to be evaluate across several types of zakat institutions in order to examine the best practice of zakat management especially for distribution purposes.

This paper focused about the relationship between quality audit committee and effectiveness internal audit function on the quality of zakat distribution performance. Thus this study intends; 1 ) to evaluate the of level of quality of zakat distribution performance; 2) to identify the relationship between the quality audit committee on the quality of zakat distribution performance and 3) identify the relationship between the effectiveness internal audit function on the zakat distribution performance. These papers review the literature as well as the research hypothesis.

\section{Literature Review}

\section{Organizational Performance in Non-profit Organization}

Nowadays, non-profit organization especially on charities have become increasingly important, as government and donors, clients and public have increased pressure on charities to demonstrate their impact on complex social problems. Even more, by given the privileged status as tax-exempted organisations, charities are expected to act as responsibly and ethically institutions who manage funds from donors, government and foundations to carry out their mission in the interest of public good (Boateng, Akamavi, \& Ndoro, 2016). For example, the administration of charitable institution of zakat (Cadge \& Wuthnow, 2006) has been in Malaysia for quite some time now, and zakat can be deducted from individual income tax under the Income Tax Act 1967 Section 6A (3) for the current year (Lembaga Hasil Dalam Negeri, 2012) Apart from that, in Malaysia, zakat payment is tax deductible for tax up to 100 percent. This mean that those who pay zakat are exempted from paying income tax at the rate zakat is paid.

Additionally, the significance of constitutes performance measurement for non-profit organization is established in the way it influences the institution behaviours, capabilities, and outcomes (Francosantos \& Bourne, 2012). However, what the best measures of performance are in charitable organisations and broadly speaking in non-profit-making organisations has been extensively debated over the past two decades in the academic press. In fact, Glassman and Spahn (2012) and; Sowa, Selden and Sandfort (2004) reveal that no agreement has emerged as to what constitutes organisational performance and how to measure it. 
Weerawardena, McDonald, and Mort (2010) in their study discover five broad measures of performance of non-profit organization: financial measures; stakeholders' engagement; internal processes; articulated activities and mission with stakeholders; learning and growth and risk mitigations. These indicated that the overall performance of non-profit organization is best measured by a set of factors that reflect the multiple and diverse stakeholders. With regards to Weerawardena et al. (2010) in the investigation on sustainability of non-profit organizations, there are need for organizational sustainability impacts on the strategic direction and operational efficiency of the nonprofit organization.

In a likely manner, Boateng et al. (2016) in their research has provided a framework for performance measurement to inspire confidence and accountability in the charity sector, besides helps to reduce the potential for scandal and promotes increased charitable giving. Based on their research, five broad sets of factors that measure performance of charities have been suggested, namely financial measures; client/customer satisfaction; management effectiveness; stakeholder involvement; and benchmarking. Besides, the broad set of performance measures above integrated with both financial and non-financial measures. Sayedi (2016) echoes the same view and suggests that charities should measure the performance complement with other measurement tools such as balanced scorecard.

Currently, funders, donors, managers, and others primarily use financial reporting to evaluate performance of not-for-profit organizations (Engel, 2016). Although these financial indicators are very important, they alone cannot provide comprehensive information on organizational performance. Managers of not-profit organizations have the fiduciary responsibility to efficiently manage resources provided by donors and members efficiently and to act as stewards for these resources which also refers to non-financial indicators (Boateng et al., 2016). As has been noted, they are also responsible for the overall performance of the not-for-profit organization. For this reason, they should also measure whether the not-for-profit organization is using the donated money effectively and ethically to achieve its mission. This statement is consistent with the performance evaluation of zakat institution in Malaysia, which needs to be measure, since it is the formal Islamic Institution have full mandate for collection zakat funds and distributed to the recipients.

\section{Quality of Zakat Distribution Performance}

Particularly, the issues on inefficiency of zakat distribution have affected the confidence of the Muslim community. Two evidence of the in efficiency of zakat distribution are the surplus of undistributed zakat (Eza Ellany et al., 2014) and the failure in distributing the funds to all categories of recipients with consider on their priority (Abd Halim, Mohamed Saladin, et al., 2015; Eza Ellany et al., 2014). Both the cause of this inefficiency has affected the confidence of zakat payers to pay funds to zakat institutions. According to Eza Ellany et al. (2014) the surplus of undistributed of zakat can be seen as an indicator of the efficiency of financial performance. Besides, the distribution of zakat by priority of recipients becomes the indicative for the efficiency on non-financial performance.

Quality of distribution performance will be determined based on the justice of efficiency according to the recipients. The study will conduct validation of content (content validity) based on the distribution view recommended by Shafi'i madhab and form the efficiency score according to the 
recipients. The non-efficiency score is formed by total of differences score between the scores of Shafi'i madhab of real distribution with the scores distribution for the eight categories of Zakat institutions recipients and divided by the difference in maximum score that can be obtained by the eight categories of recipients (Hairunnizam et al., 2016; Eza Ellany et al., 2014; 2009; Mohamad Uda, 2005). The priority efficiency score of recipients formed by the interests of the recipients who must take precedence in the order as stated in the Qur'an and Sunnah, based on Imam Shafi'i madhab. The study is to verify the content validity based on the recommended distribution ratio and score based based on Shafi'i madhab (Mohamad Uda, 2005).

\section{Quality of Audit Committee and Performance}

There are limited studies which examine direct relationship between the quality of audit committee and performance of organizations. Hasnah, Muhamad and Pheng (2005) state that the KLSE (nowadays known as Bursa Malaysia) requirements related to the audit committee of the audit committee composition, terms of reference, the meeting and the agenda of the audit committee, the audit committee and a summary of the activity reports of the internal audit activity. Hasnah (2009) emphasized the same characteristics in ensuring the quality of the audit committee. (Bansal \& Sharma, 2016) supported that frequent audit committee meetings improve the performance of some corporate governance mechanisms. This could be due to timely detection of financial statement frauds and presentation of actual financial position in front of board of directors.

Sarkar (2013) believe that independent members of the committee could fairly look into financial statements and observe components such as equity, net income, total assets and sales, which represent the performance. Similarly, Szczepankowski, (2012) have made observations of the audit committee practices in Polish listed companies in Poland and suggested that the quality of the composition of the audit committee as freedom committee and incoming directors of financial expertise on the committee is positively related to firm performance. These means that the audit committee needs for to have expert member with financial knowledge (Hasnah, 2009).

Conversely, Al-Matari, Al-Swidi, Faudziah Hanim, and Al-Matari (2012) found that the audit committee meeting were found to be as expected directions but insignificantly related to firm performance measure. However, Arslan, Zaman, Malik, and Mehmood (2014) mentioned that independent audit committees improved the quality of audit reports and enhanced performance of firm. Based on several scholars above shows that audit committee on performance should be taking into consideration, thus another view of the feature will be able to be studied on its effect on performance.

\section{Effectiveness of Internal Audit Function and Performance}

Internal auditing is widely recognized as a critical component of an organization's governance system (Bame-Aldred, Brandon, Messier, Rittenberg, \& Stefaniak, 2013; Greg Burton, Emett, Simon, \& Wood, 2012; Audrey A. Grambling, Maletta, Schneider, \& Church, 2004). According to the framework of corporate government proposed by the Institute of Internal Auditors (IIA), an effective IA is one of the four cornerstones of governance, along with the audit committee of the board of directors, 
executive management and the external auditor (IIA, 2014). Others echo the same view on the relations between effective internal audit function and performance of the organization is difficult to explain directly (Hutchinson \& Mazlina, 2009). Prior studies related to the internal audit function are the relationship of these mechanisms with the quality of audits of financial statements and performance of internal audit work which directly influences the performance of the organization.

According to Mazlina et al. (2006) the quality of internal audit, internal audit unit size and the number of experienced internal auditors audit was significantly related to the assessment of internal auditors who contributed to the work of the external audit. They distributed a 504 survey question to the chief internal auditors of companies listed on the Main Board of the KLSE. The results of Mazlina et al. (2006) showed, the main reason for the lack of cooperation between internal and external auditors, and the low level of dependence on the external auditor of internal audit work is due to a lack of qualified internal audit staff and the small size of most of the internal audit department or unit. Similarly, Ho and Hutchinson (2010) documented that the size of the internal audit unit affect the external auditor's reliance on internal audit work, including activities conducted by internal auditors.

Internal auditors must possess the knowledge, skills, and other competencies that are needed to achieve their individual responsibilities and the only way for internal auditors to continue this professional conduct is by undergoing proper training and development programs. Mihret \& Yismaw (2007) revealed that internal audit office constantly face the problem of low technical staff proficiency and high staff turnover, which would limit its capacity to provide effective service to management. Besides, the auditors' competency determines the effective auditing in the organization (Mihret \& Yismaw, 2007). Thus, the ability of the auditors to perform the systematic and disciplined audit approaches improves the effectiveness of internal audit.

\section{Hypothesis}

The relationships between quality audit committee and quality of zakat distribution performance Norazlina and Abdul Rahim (2015) found the existence of an audit committee is able to increase the performance of zakat institutions. The quality of audit committee would act as a watchdog to increase control over the institutions and thus enhance organizational performance. In accordance with agency theory, Szczepankowski (2012) found that the theoretical results like quality audit committee independence of the audit committee and incoming directors with financial expertise in accountability audit committee is positively related to firm efficiency. Besides, independent members of the committee must have sufficient knowledge in financial that enable to observe components such as equity, net income, total assets and sales, which represent the performance and financial position of the firm (Sarkar, 2013).

Not only the composition of audit committee knowledge, (Al-Mamun, Yasser, Rahman, Wickramasinghe, \& Nathan, 2014) reviewed that regular meetings of audit committee could help reduce agency problems and information asymmetry of a firm by providing fair and timely information to investors. Other characteristics also can discover the quality of audit committee. In addition, Bursa Malaysia (2016) state that there should be a characteristic for a quality audit 
committee is an audit committee composition, terms of reference, the meeting and the agenda of the audit committee, the audit committee and a summary of the activity reports of the internal audit activity. The study assumes the existence of an audit committee that coupled with certain quality characteristics, can also help improve the performance and improve the distribution of zakat institutions governance. And the first hypothesis:

There is significant relationship between audit committee and zakat distribution performance.

The relationships between internal audit function and quality of zakat distribution performance Agency theory suggests internal audit function can help owners overcome some of the problems the information gap and monitor management's activities in a cost-effective (Adams, 1994). In addition, Hasnah (2009) believe that the criteria for the quality of the internal audit function are related to the factors taken into account by the external auditors before using the work of internal auditors. (AlTwaijry, Brierley, \& Gwilliam, 2004) specifies the size of the internal audit unit and internal auditors who viewed expertise through experience is a guide to external auditors in determining the quality of an internal audit function.

Mazlina et al. (2006) found the size of the internal audit unit and the number of experienced internal auditors audit was significantly related to the assessment of internal auditors who contributed to the work of the external audit. There is no direct or indirect relationship between the qualities of the internal audit function with organizational performance (Hutchinson \& Mazlina, 2009). This is because the relationship between the internal audit function effectively with performance varies according to the characteristics of the organization and there are various factors that could affect that relationship (Hutchinson \& Mazlina, 2009). Alaswad \& Stanišić (2016) also agreed that the role of qualification and experience of internal auditor able to improve firm performance. In addition, Pizzini et al. (2014) also believe size of internal audit unit together with other characteristics of such as experience and competency training also would measure internal audit function quality.

A strong relationship exists between internal audit quality and firm performance with opportunities of high (Hermanson \& Rittenberg, 2003; Hutchinson \& Mazlina, 2009). However, Ejoh \& Ejom (2014); Kiabel (2012); Mihret et al. (2010) found that where internal auditing exists, does not significantly impact these enterprises' financial performance. These indicate the conclusion that the internal audit function differ in different types of the organization.

For the purposes of this study, internal audit function is assume to act as a control tool for the management of zakat fund operation in ensuring transparent management operation without any activity embezzlement and abuse by amil zakat or manager. The study assumes the effective internal audit function measured by the size of the internal audit unit, the number of experienced and training hours of internal auditor in the internal audit unit. In addition, the experience auditor will be able to monitor zakat institution management process, including risk management, governance and operations. This indirectly helps improve the performance of the distribution of zakat institutions. The second hypothesis: 
INTERNATIONAL JOURNAL OF ACADEMIC RESEARCH IN BUSINESS AND SOCIAL SCIENCES

Vol. 8, No. 12, Dec, 2018, E-ISSN: 2222-6990 @ 2018 HRMARS

H2 There is significant relationship between internal audit function and zakat distribution performance.

\section{Research Methodology}

The study will used secondary data sources covering the period of seven years between the years of 2010 to 2016. Generally, data relating to audit committee and internal audit function of zakat can be obtained from secondary data, namely the annual report and website of zakat institutions. However, the availability of this data is limited for some of zakat institution that do not publish annual reports in their website or some of the data require are not available. In this circumstance, the study will obtain data by using survey questions for the relevant data. Therefore, the multi method quantitative will be a complementary technique for data collection in the unavailability of some information from the secondary source (Seawright, 2016). Ordinary Least Square will be used for testing every hypothesis to meet the objectives of the second and third objectives of the study. Lastly, the method of data analysis that will be used is the Statistical Package for the Social Science (SPSS) version 22.0.

Table 1 shows a summary of operating variables.

Summary of the Variables and Measurements

\begin{tabular}{|c|c|}
\hline Variable & Measurement/Proxy \\
\hline \multicolumn{2}{|l|}{ Dependent Variable } \\
\hline $\begin{array}{ll}\text { Quality } & \text { of } \\
\text { Distribution }\end{array}$ & $\begin{array}{l}\text { Total score differences for } 8 \text { categories of asnaf (real } \\
\text { distribution score - institution distribution score) }\end{array}$ \\
\hline $\begin{array}{c}\text { Performance } \\
\text { - Priority of Asnaf Score } \\
\text { Independent Variable }\end{array}$ & 26 (Total difference in maximum score) \\
\hline $\begin{array}{l}\text { 1. Number of } A C \text { meeting } \\
\text { (ACMEET) }\end{array}$ & $\begin{array}{l}\text { Dichotomous variable equal to } 1 \text { if the number of } A C \\
\text { meetings } \geq \text { four times a year and } 0 \text { if the number of } A C \\
\text { meetings at }<\text { four times a year. }\end{array}$ \\
\hline $\begin{array}{l}\text { 2. Summary of the } A C \\
\text { activities (ACSUM) }\end{array}$ & $\begin{array}{l}\text { Dummy. } 1 \text { if the AC have a summary of the activities and } \\
0 \text { if otherwise. }\end{array}$ \\
\hline $\begin{array}{l}\text { 3. Internal audit activities } \\
\text { report (IAAR) }\end{array}$ & $\begin{array}{l}\text { Dichotomous variable equal to } 1 \text { if the } A C \text { review the } \\
\text { internal audit activities report and } 0 \text { if otherwise. }\end{array}$ \\
\hline $\begin{array}{l}\text { 4. Number of experience } \\
\text { auditor (IAEXP) }\end{array}$ & $\frac{\text { Number of experience internal auditor }}{\text { Total number of internal auditor }}$ \\
\hline
\end{tabular}


INTERNATIONAL JOURNAL OF ACADEMIC RESEARCH IN BUSINESS AND SOCIAL SCIENCES

Vol. 8, No. 12, Dec, 2018, E-ISSN: $2222-6990$ C 2018 HRMARS

\section{A Proposed Research Model}

Based on the discussion above, the proposed research model is as presented in Figure 1.

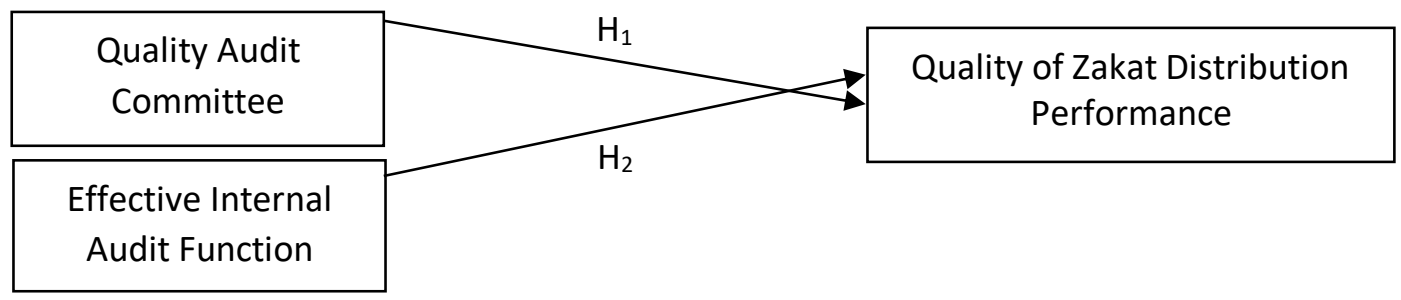

Figure 1. Proposed model of the study

\section{Conclusion}

Zakat institutions are the most trusted body by Muslim community in Malaysia as the mandate given to collect and distribute the funds of zakat. Therefore, management of zakat institutions have to be directed and managed effectively in a good manner. The quality audit committee, internal audit function and quality of zakat distribution performance in Malaysia is important to fulfil the aim of the organization. This study will open the minds of all parties that management through a good management tool can help the organization to achieve their objectives. Through the good governance practices, zakat distribution performance can be improved. Thus, a more transparent and fair distribution of zakat can be implemented in ensuring the well-being of Muslims in Malaysia. The zakat distribution by zakat institutions is not something that can be taken lightly. Allah s.w.t. has ordered that every zakat fund should be distributed fairly to qualified asnaf. Therefore, zakat institutions should accept these responsibilities and provide the best service in carrying out the mandate entrusted. Therefore, this research should be explore more in future to order to provide an establish result between of quality audit committee and effectiveness internal audit function and its relationship with the quality of zakat distribution performance.

\section{Corresponding Author}

Norlizawati Abd Rahman

Commerce Depertment, Politeknik Sultan Azlan Shah, Tanjong Malim, Perak.

Email: norlizawati@psas.edu.my

\section{References}

Abd Halim, M. N., Mohamed Saladin, A. R., Rozman, M. Y., Siti Mariam, A., \& Rashidah, A. R. (2015). Efficiency of Islamic institutions: Empirical evidence of zakat organizations' performance in Malaysia. Journal of Economics, Business and Management, 3(2), 282-286.

Adams, M. B. (1994). Agency theory and the internal audit. Managerial Auditing Journal, 9(8), 8-12. Al-Mamun, A., Yasser, R., Rahman, A., Wickramasinghe, A., \& Nathan, T. M. (2014). Relationship between audit committee characteristics, external auditors and economic value added (EVA) of 
Public Listed Firms in Malaysia. Corporate Ownership \& Control, 12(1), 1-12.

Al-Matari, Y. A., Al-Swidi, A. K., Faudziah Hanim, F., \& Al-Matari, E. M. (2012). Board of directors, audit committee characteristics and performance of Saudi Arabia Listed Companies. International Review of Management and Marketing, 2(4), 241-251.

Al-Twaijry, A. a. M., Brierley, J. a., \& Gwilliam, D. R. (2004). An examination of the relationship between internal and external audit in the Saudi Arabian corporate sector. Managerial Auditing Journal, 19(7), 929-944.

Alaswad, S. A. M., \& Stanišić, M. (2016). Role of internal audit in performance of Libyan financial organizations. International Journal of Applied Research, 2(2), 352-356.

Arslan, M., Zaman, R., Malik, R. K., \& Mehmood, A. (2014). Impact of CEO duality and audit committee on firm performance: A Study of Oil \& Gas Listed Firms of Pakistan. Research Journal of Finance and Accounting, 5(17), 2222-2847.

Audrey A. Grambling, Maletta, M. J., Schneider, A., \& Church, B. K. (2004). The role of the internal audit function in corporate governance: $A$ synthesis of the extant internal auditing literature and directions for future research. , 23, 194. Journal of Accounting Literature, 23, 194-244.

Bame-Aldred, C. W., Brandon, D. M., Messier, W. F., Rittenberg, L. E., \& Stefaniak, C. M. (2013). A summary of research on external auditor reliance on the internal audit function. Auditing, 32(SUPPL.1), 251-286.

Bansal, N., \& Sharma, A. K. (2016). Audit committee, corporate governance and firm performance: empirical evidence from India. International Journal of Economics and Finance, 8(3), 103-116.

Boateng, A., Akamavi, R. K., \& Ndoro, G. (2016). Measuring performance of non-profit organisations: Evidence from large charities. Business Ethics, 25(1), 59-74.

Bursa Malaysia. (2016). Chapter 15- Corporate Governance. Bursa Malaysia Listiing Requirement. Retrieved May 13, 2017, from https:// doi.org/10.1017/CBO97 81107415324.004

Cadge, W., \& Wuthnow, R. (2006). Religous and the non profit sector. In The nonprofit sector: A research handbook.

Ejoh, N. O., \& Ejom, P. E. C. (2014). The effect of internal audit function on the financial Performance of Tertiary. International Journal of Economics, Commerce and Management, 2(10), 1-14.

Engel, C. J. (2016). A primer on the accounting and reporting requirements for not-for-profit organizations. Journal of Public Management Research, 2(1), 14.

Eza Ellany, A. L., Mohd Rizal, P., \& Mohamat Sabri, H. (2014). Prestasi kecekapan agihan kewangan dan bukan kewangan di kalangan institusi zakat di Malaysia. Jurnal Ekonomi Malaysia, 48(2), 5160 .

Franco-santos, M., \& Bourne, M. (2012). Contemporary performance measurement systems: A review of their consequences and a framework for research. Management Accounting Research, 23(2), 1-85.

Fuadah, J., Ahmad Fahme, M. A., \& Muhammad Ridhwan, A. A. (2015). A review of literatures on current zakat issues: An analysis between 2003 - 2013. International Review of Research in Emerging Markets and the Global Economy, 1(2), 336-363.

Glassman, D. M., \& Spahn, K. (2012). Performance Measurement for Nonprofits. Journal of Applied Corporate Finance, 24(2), 72-77.

Greg Burton, F., Emett, S. A., Simon, C. A., \& Wood, D. A. (2012). Corporate managers' reliance on 
INTERNATIONAL JOURNAL OF ACADEMIC RESEARCH IN BUSINESS AND SOCIAL SCIENCES

Vol. 8, No. 12, Dec, 2018, E-ISSN: 2222-6990 @ 2018 HRMARS

internal auditor recommendations. Auditing, 31(2), 151-166.

Hafizah, Z., Azizi, A. B., \& Ram Al Jaffri, S. (2016). Reputation, satisfaction of zakat distribution, and service quality as determinant of stakeholder trust in zakat institutions. International Journal of Economics and Financial Issues. 6(S7), 72-76.

Hairunnizam, W., Sanep, A., Mohd Ali, M. N., \& Maryam, A. R. (2016). Prestasi Kecekapan Pengurusan Kewangan dan Pengurusan Agihan Zakat: Perbandingan Antara Majlis Agama Islam Negeri. In Persidangan Kebangsaan Ekonomi Malaysia (pp. 8-9).

Hasnah, H. (2009). Kegagalan tadbir urus korporat: bagaimanakah keberkesanan mekanisme pemantauan dalaman dan luaran dapat membantu?Siri perlantikan profesor 2006 / Bil. 11. Penerbit Universiti Sains Malaysia.

Hasnah, H., Muhamad, J., \& Pheng, E. G. (2005). Audit Committee Compliance with Kuala Lumpur Stock Exchange Listing Requirements. International Journal of Auditing, 9(9), 187-200.

Hermanson, D. R., \& Rittenberg, L. E. (2003). Internal audit and organizational governance. Research Opportunities in Internal Auditing, 1, 25-71.

Ho, T. C. F., Noor Hazlina, A., \& Ramayah, T. (2016). Competitive capabilities and business performance among manufacturing SMEs: Evidence from an emerging economy, Malaysia. Journal of Asia-Pacific Business, 17(1), 37-58.

Hutchinson, M. R., \& Mazlina, M. Z. (2009). Internal audit quality, audit committee independence, growth opportunities and firm performance. Corporate Ownership and Control, 7(2), 50-63.

Kiabel, D. (2012). Internal auditing and performance of government enterprises: A Nigerian study. Global Journal of Management and Business Research, 12(6), 6.

Lembaga Hasil Dalam Negeri. (2012). Income Tax Act 1967 Section 6A (3). Retrieved May 10, 2017, from http://www.hasil.gov.my/bt_goindex.php?bt_ kump $=5 \& b t$ _skum $=5 \& b t \_p o s i=3 \& b t \_u n i t=1 \& b t \_$sequ $=2$.

Mazlina, M. Z., Subramaniam, N., \& Stewart, J. (2006). Internal auditors' assessment of their contribution to financial statement audits: The relation with audit committee and internal audit function characteristics. International Journal of Auditing Int. J. Audit, 10(March), 1-18.

Mihret, D. G., James, K., \& Mula, J. M. (2010). Antecedents and organisational performance implications of internal audit effectiveness: some propositions and research agenda. Pacific Accounting Review, 22(3), 224-252.

Mohamad Uda, K. (2005). Zakat Teori, Kutipan dan Agihan. Kuala Lumpur: Utusan Publication \& Distributors Sdn Bhd.

Norazlina, A. W., \& Abdul Rahim, A. R. (2015). Efficiency of zakat institutions and its determinants. H A El-Karanshawy et Al. (Eds.), Access to Finance and Human Development - Essays on Zakah, Awqaf and Microfinance, 1, 33-42.

Pizzini, M., Lin, S., \& Ziegenfuss, D. E. (2014). The impact of internal audit function quality and contribution on audit delays. Social Science Research Network, 34(1), 25-58.

Sani Adamu, M., \& Ram Al Jaffri, S. (2016). Determinants of trust on zakat institutions and its dimensions on intention to pay zakat: A pilot study. Journal of Advanced Research in Business and Management Studies, 3(1), 40-46.

Sarkar, S. (2013). Audit committee: Regulations and market response. NSE Quarterly Briefing, 2. 
Sayedi, M. (2016). The non-financial and financial performance evaluation of tax office using balanced scorecard. International Journal of Business Information Systems, 22(2), 30.

Seawright, J. (2016). Multi-Method Social Science: Combining Qualitative and Quantitative Tools. Cambrige Univercity Press.

Sowa, J. E., Selden, S. C., \& Sandfort, J. . (2004). No longer unmeasurable? A multidimensional integrated model of nonprofit organizational effectiveness. Nonprofit and Voluntary Sector Quarterly, 33(4), 711-728.

Szczepankowski, P. (2012). Audit Committee Practice in the Polish Listed Stock Companies. Present Situation and Development Perspectives. Business, Management and Education, 10(1), 50-65.

Weerawardena, J., McDonald, R. E., \& Mort, G. S. (2010). Sustainability of nonprofit organizations: An empirical investigation. Journal of World Business, 45(4), 346-356.

Zaemah, Z., \& Norhafiza, N. (2016). Addressing governance issue in islamic real estate investment ( IREITs ): A case study for oic country -Malaysia, International Journal of Islamic Business, 1(1), 60-75. 